
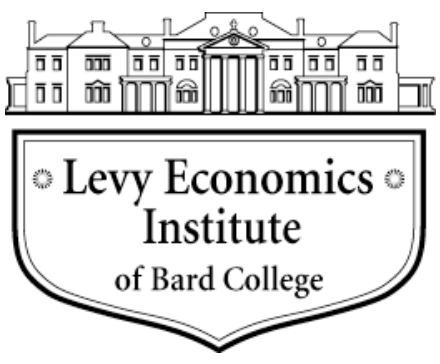

Working Paper No. 833

\title{
Emerging Markets and the International Financial Architecture: A Blueprint for Reform*
}

by

Jan Kregel ${ }^{\dagger}$

Levy Economics Institute of Bard College

\section{February 2015}

\footnotetext{
* Elaboration of a panel presentation at the Jornadas Monetarias y Bancarias of the Banco Central de la Republica Argentina, Buenos Aires, November 18, 2014.

$\dagger$ kregel@levy.org
}

The Levy Economics Institute Working Paper Collection presents research in progress by Levy Institute scholars and conference participants. The purpose of the series is to disseminate ideas to and elicit comments from academics and professionals.

Levy Economics Institute of Bard College, founded in 1986, is a nonprofit, nonpartisan, independently funded research organization devoted to public service. Through scholarship and economic research it generates viable, effective public policy responses to important economic problems that profoundly affect the quality of life in the United States and abroad.

Levy Economics Institute P.O. Box 5000 Annandale-on-Hudson, NY 12504-5000

http://www.levyinstitute.org

Copyright (C) Levy Economics Institute 2015 All rights reserved

ISSN 1547-366X 


\begin{abstract}
If emerging markets are to achieve their objective of joining the ranks of industrialized, developed countries, they must use their economic and political influence to support radical change in the international financial system. This working paper recommends John Maynard Keynes's "clearing union" as a blueprint for reform of the international financial architecture that could address emerging market grievances more effectively than current approaches.

Keynes's proposal for the postwar international system sought to remedy some of the same problems currently facing emerging market economies. It was based on the idea that financial stability was predicated on a balance between imports and exports over time, with any divergence from balance providing automatic financing of the debit countries by the creditor countries via a global clearinghouse or settlement system for trade and payments on current account. This eliminated national currency payments for imports and exports; countries received credits or debits in a notional unit of account fixed to national currency. Since the unit of account could not be traded, bought, or sold, it would not be an international reserve currency. The credits with the clearinghouse could only be used to offset debits by buying imports, and if not used for this purpose they would eventually be extinguished; hence the burden of adjustment would be shared equally_credit generated by surpluses would have to be used to buy imports from the countries with debit balances. Emerging market economies could improve upon current schemes for regionally governed financial institutions by using this proposal as a template for the creation of regional clearing unions using a notional unit of account.
\end{abstract}

Keywords: Banking Principle; Bretton Woods; Creditor Countries; Debtor Countries; Emerging Market Economies; Gold Standard; International Monetary Standard; Keynes; Reparations; Schacht; Triffin

JEL Classifications: E42, E52, F12, N44 


\section{Recent Emerging Market Critiques of the International Financial Architecture}

The developed world's policy response to the recent financial crisis has produced a growing chorus of criticism of the international financial system by emerging market government officials. The former Brazilian finance minister has complained of the currency wars generated by the extraordinary monetary policies introduced by developed country central banks in response to the Great Recession (Wheatley and Garnham 2010). Criticism was equally sharp when a possible reversal of these policies was intimated and the resulting "taper tantrum" in May 2013 produced sharp volatility in exchange rates and capital flows to emerging market economies (Wheatley 2014).

The new Indian central bank governor has joined in this criticism of the policies of developed country central banks, faulting them for failing to take into account the impact of their policies on emerging markets and calling for increased policy coordination and cooperation (Goyal 2014, Spicer 2014). Seeking a larger international role for the Chinese currency, Chinese officials have also called into question the dominant role of the US dollarechoing a criticism of the "exorbitant privilege" first launched by French President de Gaulle in the 1960s. ${ }^{1}$ And even before its current difficulties in managing the impact of the decline in oil prices on the ruble exchange rate, Russia joined China as a proponent of replacing the dollar with the SDR - the International Monetary Fund's Special Drawing Rights (China Briefing 2010, Reuters Factbox 2009, Oliver 2009, Zhou 2009).

These criticisms of the international financial architecture are not new-indeed, they reappear after every international financial crisis - and neither is the proposed solution: increased policy coordination, replacing the dollar with an international reserve currency, and the creation of regional or emerging-market-governed institutions to replace the US-dominated International Monetary Fund (IMF). Yet there has been little real modification of the Bretton Woods system aside from the unilateral decision of the United States in 1970 to abrogate its commitment under the IMF Articles of Agreement to support a fixed dollar-gold parity.

Not only have these proposals for reform gained little support in the past, they are unlikely to remedy the faults decried by emerging market economies. Indeed, they may make conditions facing these economies worse. This paper provides a discussion of why these reform

\footnotetext{
1 "The present monetary system consists in the exorbitant privilege enjoyed by the United States of being able to cover is balance of payments deficit with its own dollars" (February 4, 1965).
} 
proposals are of little benefit to the objective of an international financial architecture supportive of developing countries. It suggests that several of the alternatives rejected in the pre-Bretton Woods discussion could provide a basis for a more stable financial system suitable to the needs of emerging market economies. If emerging markets are to achieve their objective of joining the ranks of industrialized, developed countries, they must use their economic and political influence to support radical change in the international financial system.

\section{The Chimera of Increased Policy Coordination}

In the aftermath of the US decision to break the dollar-gold parity and the collapse of the Smithsonian Agreements to preserve fixed exchange rates, virtually the only role that remained for the IMF was policy coordination to ensure exchange rate stability. Initially carried out through policy conditionality on program lending and Article IV assessments, it has now been extended to consider more systemic interconnections of national monetary and fiscal policies in the form of what is called the "Spillover Report," which seeks to identify the cross-border impact of members' economic policies (IMF 2014). But it is instructive that the attempts to charge the IMF with increased power to impose policy coordination have produced meager results, and even skepticism, among IMF staff (Blanchard, Ostry, and Ghosh 2013). It is instructive that even the modest attempts to adjust emerging market quotas and governance in the Fund, agreed to after the 1997 Asian crisis, have yet to be approved. Indeed, the major fora for coordination are now in the G-20 and the Financial Stability Forum, both also dominated by US policy preferences.

Even more important, there is little historical evidence that policy coordination is in any way beneficial to the stability of the international system. The best-known example of monetary policy coordination was the support provided by the governor of the Federal Reserve Bank of New York to ease the return of the pound sterling to the gold standard in the 1920s. The Fed, in response to the postwar slump in the early 1920s, supported market conditions favorable to the British objective, but the same support after the return to gold in the presence of a run-up in US securities prices is widely believed to have provided the basis for the euphoria in equity markets that led to the September 1929 market break. ${ }^{2}$ And the collateral damage of this policy was an

\footnotetext{
2 "With reference to the meeting promoted by Montagu Norman, and arranged by Benjamin Strong, including Hjalmar Schacht and Charles Rist (representing Émile Moreau), to coordinate policy in support of sterling, Stephen
} 
increasing flow of short-term funds to Germany that exacerbated the problem of finding an equitable solution to inter-Allied debts and German reparations. ${ }^{3}$

More recently, international cooperation provided the bulwark for the measures taken to resolve the dollar's overvaluation and then precipitous decline in the aftermath of the Plaza and Louvre agreements. According to Toyoo Gyohten, the failure of these coordination efforts was the main cause of the October 19, 1987, equity market break known as Black Monday. ${ }^{4}$ Subsequently, the need to allow the United States to lower rates without further depreciation of the dollar led to interest rate reductions by the Bank of Japan in the presence of a rampant equity and property bubble, which precipitated the break in the Japanese market at the end of 1989 that produced a 25 -year stagnation and the birth of the zero-interest-rate policies now lamented by emerging market economies.

A clear problem facing coordination that is cited by both Gyohten and Paul Volcker is the fact that coordination has been predominantly in monetary policy, absent fiscal policy coordination: "Whatever its economic merits, the flexible use of fiscal policy is politically difficult. This difficulty is what limits so sharply the potential for the international coordination of economic policies" (Volcker, in Volcker and Gyohten 1992, 292). These difficulties seem only to have increased in the current response to financial crisis.

Unfortunately, while policy coordination appears to have been more the rule than the exception in the past, it does not have a record of producing positive results, and there is little evidence that attempts to consider the impact of domestic monetary policies on other countries can ever be devised in such a way as to provide mutually beneficial results.

Clarke notes that "the basic instrument, as in 1924, was an easing of monetary policy which, in the light of the boom of the next two years and of the October $1929 \mathrm{crash}$, was to become one of the most controversial actions in the history of the Federal Reserve System" (Clarke 1967, 124).

${ }^{3}$ Schacht explains that "it had not been possible to comply with the demands of the Dawes Plan and pay the reparations debts out of export surplus. Not once in the course of the past five years had we achieved such a surplus. Rather, we had met all payments of reparations out of the loans made to us by other countries during those years, a system which could not possibly be continued for any length of time. The interest would increase our indebtedness year by year and the loans themselves would not always be forthcoming" $(1955,248)$.

4 "The crash drew forth a multitude of explanations, but I am convinced that one fundamental cause was the failure to achieve real results in coordinating the macroeconomic policies of the seven major economic powers" (Toyoo Gyohten, in Volcker and Gyohten 1992, 268). 


\section{An International Reserve Currency}

Since Robert Triffin's devastating critique of the Bretton Woods dollar-gold standard (Triffin 1960), the problems of using a national currency as the international reserve currency in a stable exchange rate system have been well known. But rather than providing an innovative solution to this problem, the current proposals to replace the dollar with an international reserve currency appear to be based on the belief that this could provide a system of implicit policy coordination similar to that which was supposed to have ruled under the freely convertible international gold standard. If each country were responsible for maintaining the gold content of its domestic currency unit, there would be no need for explicit international coordination; it would be imposed by the market adjustment of trade flows to changes in relative gold prices for traded and nontraded goods. However, it is difficult to see how an independent international currency would perform differently from the actual operation of the gold standard. Indeed, the Bretton Woods system was an attempt to escape the instability of the British return to the gold standard in the 1920 s.

\section{Keynes's Critique of International Standards}

As Keynes pointed out, the international coordination provided under the gold standard was neither equitable nor stabilizing: "The main cause of failure . . of the freely convertible international metallic standard," he wrote, was "that it throws the main burden of adjustment on the country which is in the debtor position on the international balance of payments" (Keynes 1980, 27). "It has been an inherent characteristic of the automatic international metallic currency ... to force adjustments in the direction most disruptive of social order, and to throw the burden on the countries least able to support it, making the poor poorer" (29).

Indeed, the historical performance of the gold standard confirms this assessment. When debtor countries are faced with adjustment via credit restriction and declining domestic prices, the pressure on the financial system leads to a suspension of the gold standard, while creditor countries resist the expansion of credit and rising prices by limiting convertibility and implementing counterinflationary policies. ${ }^{5}$ Thus, while Keynes's insistence on symmetric adjustment is often explained by a desire to allow the UK to implement policies to maximize

\footnotetext{
${ }^{5}$ The various measures used by central banks to manage the "automatic" gold standard adjustment process are detailed in Bloomfield (1959).
} 
employment and prevent systemic deficiency of global demand, it has a more fundamental explanation related to the destabilizing nature of a system based on an international standard. As Keynes observed,

The main effect of [any international standard] is to secure uniformity of movement in different countries-everyone must conform to the average behaviour of everyone else. . . . The disadvantage is that it hampers each central bank in tackling its own national problems. (Keynes 1971b, 255-56)

Thus, Keynes identified the existence of a freely convertible international standard, rather than the asymmetric adjustment, as the constraint on national policy autonomy.

In addition, Keynes noted "a further defect" in the supposed automatic coordination of adjustment under the freely convertible international standard: "The remittance and acceptance of overseas capital funds for refugee, speculative or investment purposes" $(1980,30)$. And in contrast to earlier periods, "capital funds flowed from countries of which the balance of trade was adverse into countries where it was favourable. This became, in the end, the major cause of instability" (31). His conclusion was that since "we have no security against a repetition of this after the present war . . nothing is more certain than that the movement of capital funds must be regulated" (31).

This observation reprises Keynes's view of the variable speeds of adjustment of financial and real variables:

It is, therefore, a serious question whether it is right to adopt an international standard, which will allow an extreme mobility and sensitiveness of foreign lending, whilst the remaining elements of the economic complex remain exceedingly rigid. If it were as easy to put wages up and down as it is to put bank rate up and down, well and good. But this is not the actual situation. A change in international financial conditions or in the wind and weather of speculative sentiment may alter the volume of foreign lending, if nothing is done to counteract it, by tens of millions in a few weeks. Yet there is no possibility of rapidly altering the balance of imports and exports to correspond. (1971b, 300)

Indeed, a characteristic of the post-Smithsonian, Bretton Woods system has been the tendency for international capital to flow from debtor to creditor countries. This was first seen in Europe as speculative funds flowed to Germany, forcing repeated exchange rate adjustments,

\footnotetext{
6 "During the nineteenth century and up to 1914 the flow of capital funds had been directed from the creditor to the debtor countries, which broadly corresponded to the older and the newer countries, and served at the same time to keep the balance of international payments in equilibrium and to develop resources in undeveloped lands" (Keynes 1980, 30). This is an assessment very similar to that of Raúl Prebisch concerning the impact of international capital flows on Latin American development in the 19th century.
} 
and in the global economy in the negative net flows of financial resources from developing to developed countries in the 1980s. Just as members of the euro area have not been spared financial instability with the single "interregional standard" replacing the deutsche mark, emerging market countries are not likely to find a remedy to their complaints if the dollar is replaced with the SDR or an international reserve currency.

\section{Regional/Peer Group Arrangements}

The most innovative proposals from emerging market countries have involved the creation of regional or peer group financing institutions such as the BRICS bank, the Bank of the South, and the Asian Infrastructure Investment Bank, as well as the introduction of currency swap arrangements between emerging market countries to reduce dependence on the dollar for purposes of bilateral settlement. These arrangements do not seem to escape the problems faced by the IMF in promoting coordination, aside from reducing the number of participants and ostensibly eliminating the US role. However, most of the lending arrangements include an IMF program of conditionality at some level, and thus do not escape the indirect influence of the United States. In addition, they do not solve the problem of the reference or reserve currency to be used in such institutions. And those that propose a common currency unit, such as the Bank of the South, do not resolve the problems that Keynes identified regarding the convertible international standard, or those that have been observed within the euro area in terms of providing a common, but nonoptimal, policy mix for all countries involved. Indeed, replacing the dollar with another national currency unit or an independent international unit does not eliminate the problems of emerging market economies with the operation of the IMF. A more radical solution is required-a solution that was initially discussed in the 1940s but eventually rejected because of US resistance.

\section{The Road to Radical International Reform Not Taken}

As Keynes noted in his proposals for postwar international monetary reform, the fact that the problem of maintaining equilibrium in the balance of payments between countries has never been solved, since methods of barter gave way to the use of money and bills of exchange ... [,] has been a major cause of impoverishment and social discontent and even of wars and revolutions. $(1980,21)$ 
His proposals for the post-World War II financial system sought a solution to the problem by avoiding the difficulties caused by the Treaty of Versailles, represented in his first popular book, The Economic Consequences of the Peace (1919). Indeed, it is difficult to understand any of the discussion of postwar international finance without reference to the financial problems of the Treaty of Versailles and the Dawes and Young Committees in dealing with German reparations and the debts of the Allies to the United States.

The problems caused by German reparations payments generated two fundamental principles: (1) that reparations could only be achieved through net exports of goods and services, not by fiscal surpluses and financial transfers; and (2) that this could only be achieved if the recipient country were willing to open its domestic markets and accept an external deficit. The formulation of proposals for the postwar system was dominated by the need to make sure that the absence of these two conditions, which had led to volatile international capital flows and exchange rates, should not be repeated.

As Keynes's thinking evolved, a third fundamental principle gained ascendancy, which Keynes called "the banking principle," and which he defined as "the necessary equality of debits and credits, of assets and liabilities. If no credits can be removed outside the banking system but only transferred within it, the Bank itself can never be in difficulties" $(1980,44)$. But this principle did not refer to credit creation via the creation of bank deposits. It was motivated by an application of his theory of liquidity preference and effective demand. He faulted the gold standard because saving by creditor countries in the form of holding gold stocks reduced global liquidity, and thus the ability to finance global demand.

The banking principle eventually became the centerpiece of Keynes's proposals for a clearing union in which credits were automatically made available to debtor countries to spend. This was of great advantage to the UK, since it meant that the financing of imports required for reconstruction would be automatically available without the need to accumulate dollar balances through export sales (or by borrowing from the United States). On the other hand, the States viewed it as an unlimited commitment to finance European reconstruction, making the proposal anathema to US negotiators. ${ }^{7}$

\footnotetext{
${ }^{7}$ Indeed, the private bankers' criticism of the plan was that it was bad banking, since the lending was automatic with no due diligence or credit assessment!
} 
One of the initial solutions to the reparations problem that is relevant to the concerns of emerging markets, because it took the role of developing countries into account, was proposed by Hjalmar Schacht to Owen Young during the Committee of Experts meeting in Paris in 1929: an international "Clearing House" or International Settlements Bank (see Lüke 1985). The idea behind the plan was to resolve the difficulty faced by German industry in producing for export, due to the loss of raw materials from its former colonies, and the difficulty in penetrating the export markets of its creditors. The clearinghouse was to make loans to developing countries in support of the provision of raw materials to Germany and to create markets in these countries for German exports. Schacht notes that his objective was

to take decisive action to strengthen German export trade in order to achieve a surplus. ... The economic history of the past decades had furnished convincing proof that loans should be used first and foremost to help the under-developed countries to make full use of their raw materials and gradually to become industrialized. Before the war the European capital markets had supplied the funds in connection with loans for the economic advancement of the underdeveloped South American and Balkan States and many other overseas territories. England, France, Germany, etc., had not been in need of foreign loans: on the contrary they had been creditors and suppliers of capital to underdeveloped countries. Germany was now an impoverished country and no longer able to make loans to others. If the Allies really wished to help her to meet her reparations liabilities they should grant loans to the under-developed countries, and thereby put the latter in a position where they would be able to purchase their industrial equipment in Germany. No useful purpose would be served by allowing Germany to compete in existing world markets against other European industrial states as she had hitherto done. (Schacht 1955, 247-8)

This objective was never realized, but the proposal formed the basis for the Bank for International Settlements, with the reduced objective of managing reparations payments. ${ }^{8}$ The reform plans that were discussed in the early 1940s were built on another of Schacht's schemes: the "New Plan," based on bilateral "Clearing Accounts." As economics

\footnotetext{
${ }^{8}$ The scheme was an early representation of a special purpose vehicle owned by the major central banks and capitalized with a special issue of five billion gold marks of German discount bonds to support the granting of book credits to central banks, governments, and other guaranteed borrowers to promote lending to developing countries. Since the loans "were only to be granted in the form of book credits, ... repayments would be made either from another account with the same institution or in cash, and ... the central banks would be able to utilise the credits they obtained as cover for their respective currencies. Thus, the German obligations were to be used as a basis for international credit expansion, making it possible to mobilise the claims on Germany up to an amount of 10 billion Gold Marks ... promptly and without any transfer difficulties, since the transfer could only be effected by transfer from one account to another" (Lüke 1985, 73). Since Germany could not qualify for lending, "the American delegation saw in it a device ... to expose Germany's neighbour and creditor countries to inflation," and thus the plan was never implemented.
} 
minister, he applied the "very simple principle that Germany must refrain from buying more than she could pay for, in order to prevent an accumulation of foreign debt which would make a proper trade balance still more difficult to establish in the future" (Schacht 1949, 80). Given that the creditor countries' "system of import quotas had closed markets to German goods," Schacht sought

to find countries which would be willing to sell their goods not against payment in their own currency, but against ... German goods. ... The best solution was the establishment of "clearing accounts." Foreign countries selling goods to us would have the amount of our purchases credited to their account in German currency, and with this they could then buy anything they wanted in Germany. $(1949,80-1)$

Since Germany was in bilateral deficit with most countries, this led to "blocked credit balances" "of Reichsmarks, or what were called "Sperrmarks," that could only be used for specific types of payments - either to foreign exporters or bondholders, leading to a demand for German exports to release them. As Johan Beyen notes,

[creditor] governments had to square the account with whatever Germany was prepared to deliver; and they were inclined to do so because the German purchases solved their unemployment problem. There may be some exaggeration in the story that the Balkan countries had to buy mouthorgans none of its inhabitants cared to play on, or aspirin in quantities that could have poisoned the whole populations ... clearing agreements enabled the German government to "modulate" its imports and exports and to adapt its international trade to its needs for rearmament. (Beyen 1951, 106-7)

Thus, it was not Schacht's 1929 clearinghouse plan, but his system of bilateral clearing agreements that provided the blueprint for both the Keynes and White plans for a stable international financial architecture. Keynes expressed these initial ideas for the postwar system in these terms: "The virtue of free trade depends on [it] being carried on by means of what is, in effect, barter. After the last war laissez-faire in foreign exchange led to chaos" $(1980,8)$. He noted in this regard that it was Schacht who provided

the germs of a good technical idea. This idea was to [discard] the use of a currency having international validity and substitute for it what amounted to barter, not indeed between individuals, but between different economic units. In this way he was able to return to the essential character and the original purpose

\footnotetext{
${ }^{9}$ Without this background it is difficult to understand the amount of space given in the US proposal to such balances, and the concern of the UK for resolution of the sterling balances with its Commonwealth partners in any postwar scheme.
} 
of trade whilst discarding the apparatus which had been supposed to facilitate, but was in fact strangling, it. (23)

But Keynes assured his critics that this "does not mean that there would be direct barter of goods against goods, but that the one trading transaction must necessarily find its counterpart in another trading transaction sooner or later" (18).

Keynes's proposal was based on the simple idea that financial stability was predicated on a balance between imports and exports, with any divergence from balance providing automatic financing of the debit countries by the creditor countries via a global clearinghouse or settlement system for trade and payments on current account. This eliminated national currency payments for imports and exports; countries received credits or debits in a notional unit of account fixed to the national currency. Since the unit of account could not be traded, bought, or sold, it would not be an international reserve currency. The implication was that there would be no need for a market for "foreign" currency or reserve balances, and thus no impact of volatile exchange rates on relative prices of international goods, or tradable and nontradable goods. In addition, the automatic creation of credit meant that the UK would not be constrained by its nonexistent gold reserves or its nonexistent dollar balances in financing its reconstruction needs for imports. ${ }^{10}$

Since the credits with the clearinghouse could only be used to offset debits by buying imports, and if not used for this purpose they would eventually be extinguished, the burden of adjustment was shared equally: credit generated by surpluses had to be used to buy imports from the countries with debit balances. Alternatively, they could be used to purchase foreign assetsforeign direct or portfolio investment - but the size of these purchases would be strictly limited by the size of the surplus country's credit balance with the clearinghouse. Once a limit on the size of multilateral debits and credits was agreed upon for each country_its "quota" — penalties, in the form of interest charges, exchange rate adjustment, forfeiture, or exclusion from clearing, would be applied and the outstanding balances would automatically be reduced. Although Keynes's initial proposals did not take developing countries into account, the subsequent drafts suggest that the interest charges on the credit and debit balances generated could be provided as

\footnotetext{
${ }^{10}$ Note that while Schacht's 1929 clearinghouse proposal was to create financing and demand for its exports, Keynes's clearinghouse was to create sources of financing for its clear need for reconstruction imports in the face of lost export markets and overseas assets. Just as the Allies were unwilling to open their markets to German exports in World War I, the United States was unwilling to provide what was represented as an unlimited credit for UK imports; the US proposal thus required smaller upfront collateral commitments to join the scheme.
} 
additional credits to support the clearing accounts of developing ("backward") countries (1980, 120).

Another advantage that Keynes claimed for his plan was that it was multilateral in nature, by contrast with Schacht's bilateral clearing agreements. It also avoided the problem of blocked balances and multiple exchange rates for different types of balances and different countries, which had been prevalent within the exchanges under the bilateral agreements. Both of these attributes were considered to be primary objectives of any postwar arrangement and were also present in the US proposal and expressly included in the Final Act of the Bretton Woods agreements.

\section{Keynes Was Not Alone in Proposing the "Clearing" Solution}

Keynes was not alone in proposing a "clearing" bank as the basis for reform of the international system in the $1940 \mathrm{~s} .{ }^{11}$ A similar scheme, more closely linked to the then-current system of trade bills as settlement under the gold standard, appeared in an anonymously published pamphlet, "A Twentieth Century Economic System," thought to have been penned by William Francis Forbes-Sempill, 19th Lord Sempill. ${ }^{12}$ It argued that

it is necessary to establish a system of international trade under which the problem will be fairly and squarely placed on the shoulders of each nation, as to how it proposes to take payment for its exports: if it does not take payment in the form of imports, it will merely have made a present of its exports. The matter will then be one for settlement, not as between nations, but within each nation as between the exporting industries, which will wish to continue to export, and the new industries, which will be faced by the dilemma of seeing their best customers, the export industries, ruined, or allowing imports in to pay for those exports. . . . The United States has already shown the way to the new system in the Lease-Lend Act. She has there accepted the principle that nations can only pay for goods and services with goods and services. (Economic Reform Club 1941, 29-30)

\footnotetext{
${ }^{11}$ A note in volume 25 of Keynes's Collected Works (1980, 21, n. 5) indicates that Keynes received a draft plan for a clearing union arrangement written by E. F. Schumacher, but that there is no indication that it had any influence on the development of Keynes's ideas.

12 Published by the Economic Reform Club with a preface dated August 1941, the pamphlet was issued in at least three editions totaling 16,000 copies from November 1941 through June 1942. Keynes's initial clearing union drafts date from December 1940. The contents of the pamphlet were presented by Lord Sempill in a House of Lords debate (Sempill 1941) and in subsequent debates on the issue of postwar planning (Parl. Deb., H.L. [5th ser.] [1942] 115-78; [1943] 102-9). A negative review of the document in the Australian Social Crediter (1943) indicates Sempill was the author. Economic Reform Club members were linked to anticommunist, fascist, and antiSemitic groups. Sempill, a close confidant of Churchill, was later confirmed as a spy for the Japanese and credited with providing support and incitement for the attack on Pearl Harbor.
} 
The proposal called for the creation of an "international exchange" or "clearing bank" that would deal in foreign exchange trade bills issued to finance trade in goods and services. For example, a US exporter who draws an exchange bill on the UK importer creates a claim on the UK, which he discounts at his local bank for dollars. The exporter's bank then discounts the bill with the US Exchange Control Agency against the proof of shipment of the goods. The US Control Agency thus holds a sterling claim that could be sold to a US importer who has a bill drawn against him by a UK exporter. It is thus the US importer who pays dollars to the US exporter in place of the UK importer. A similar offset occurs when the UK importer honors the bill by paying in sterling at his local bank, which receives a sterling credit with UK Exchange Control, which in turn now has a dollar claim available for sale to a UK importer. Since all transactions are between domestic residents in the same domestic currency, "international trade would ... be done by a system of contra account" (Economic Reform Club 1941, 32). The proposal notes that in this way the confrontation is between importers and exporters in the same country - rather than a competition among countries over their trade balances - and as such a benefit to global peace. ${ }^{13}$

This is in fact the way trade was financed under the gold standard, through the use of sterling bills in London, with the exception that imbalances were adjusted by means of the flow of short-term finance bills between the two countries. ${ }^{14}$ When an imbalance became so large that it caused a movement in the exchange rate beyond the costs of shipping gold - the gold pointsthen gold would be physically transferred and the exchange rate would return toward par.

However, in this system, the exchange agencies would agree to hold credit balances up to a specified level, eliminating the need for short-term financing. It reproduces Keynes's objective of symmetric adjustment between creditors and debtors by proposing that "the importing country [i.e., net debtor] would be entitled to cancel the credit, under a Statute of Limitations, if it were not used within seven years" (Economic Reform Club 1941, 33). The system becomes multilateral when the national exchange control agencies of all countries hold accounts in an international exchange clearing bank where credits can be exchanged at fixed

\footnotetext{
${ }^{13}$ This reflects Keynes's use of "units" in describing Schacht's plan, which pitted interests of exporters against debt holders. Here it is the interests of importers and exporters.

${ }^{14}$ Keynes provides a description of this system in the last chapter of the Tract on Monetary Reform (1971a), where he notes that it would be compromised by the suspension of the gold standard and suggests the creation of forward markets to provide banks with the exchange rate hedging previously provided by the gold points.
} 
notional exchange rates with national currencies against third countries. In both systems, the creation of credit for debtor countries is automatic, due to the clearing arrangements, and thus independent of exchange and capital markets. Each has the advantage of automatically providing the postwar credits needed by deficit countries, without the need to acquire gold or other means of payment.

Both of these proposals are grounded in the belief that imports can only be paid with exports and that international financial stability requires constraining current account imbalances within clear limits, which by extension places similar limits on the degree of capital account accommodation of deficits and the buildup of a country's external indebtedness. In practice, imbalances are limited by the administrative and monetary sanctions placed on the size of debit and credit balances through multilateral negotiation by members of the clearinghouse. National currencies are maintained and national policy autonomy is preserved within the limits of the permitted divergence from external balance. Exchange rate levels and adjustments are also determined by multilateral negotiation within the clearinghouse, compatible with external equilibrium. Keynes's plan uses a notional unit of account - bancor — but it is not necessary, as the same result could be achieved by setting notional bilateral exchange rates in a multilateral clearing system, as in the Sempill proposal. The schemes thus provide an improvement on the Schachtian approach by eliminating managed bilateral trade, multiple exchange rates, and currency manipulation. Indeed, in his maiden speech to the House of Lords, Keynes cited the multilateral nature of these schemes as their basic contribution.

\section{Similarities between the Clearing and Stabilization Plans}

At this level, it is understandable that Keynes could consider the US proposals for a stabilization fund as broadly similar to his own, for they were based on the same two principles outlined above and a belief in the importance of external balance, and included similar limitations on the size of the imbalance, given by access to the gold tranche and additional conditional Fund lending subject to multilateral consultation. ${ }^{15}$ Although asymmetric adjustment was not formally included, Article VII on scarce currencies provided that Fund shortages of a currency (e.g., a dollar shortage, representing an excessive US credit balance), would trigger limitations on the

\footnotetext{
${ }^{15}$ From Keynes's maiden speech to the House of Lords (1943): "Most critics, in my judgment, have overstated the differences between the two plans, plans which are born of the same climate of opinion and which have identical purpose."
} 
ability to finance dollar imports and thus permitted discrimination against US exports to force adjustment (although Keynes was skeptical that it would ever be invoked).

\section{Differences between Clearing Banks and Stabilization Funds}

However, there were two basic differences that caused a radical change in Keynes's thinking about financial system reform. The first was the realpolitik realization that US cooperation was required, and that the United States would not accept his clearing union proposal. This meant that the third principle of Keynes's approach - the banking principle - would be abandoned. There would be no automatic financing of the British needs for reconstruction via clearing credits from the United States, making the loan negotiations with the US necessary. In place of automatically granted credit would be decisions by the Fund that eventually produced conditionality on access above the gold tranche, leading the UK to seek greater autonomy, in particular over exchange rate adjustments. It also meant that the Fund could not be used for the pressing problems of European reconstruction, which would be taken over by the Bank (and explains Keynes's sudden interest in formulating that institution). There was thus no need for speed in initiating Fund operations, accepting a point that John Williams (1949) had stressed in his "Key" currency proposals (although there was a need to have ratification before political interest waned). Nonetheless, Keynes was willing to work to improve the US scheme in the belief that it was important to take action to restore multilateral clearing, and US participation was crucial to this objective.

\section{And a Fundamental Difference: "I Didn't See that Coming"}

However, the greatest difference, and one that Keynes would surely have resisted, emerged only in the last minutes of the Bretton Woods negotiations and appeared unnoticed until the specifics of the Final Act were distributed: the role of the dollar at the center of the system. There is no mention of the role of the dollar in either the White Plan or the Joint Ministerial Statement. Yet, according to Armand Van Dormael,

Putting the dollar next to gold at the centre of the postwar monetary system had been uppermost in Harry White's mind ever since he started thinking about the subject. . . In September 1943 Keynes told White that the United Kingdom did not contemplate going on to a gold or a dollar standard. ... Whenever the matter 
was brought up, he categorically rejected the idea that the dollar should be given a special status. ${ }^{16}$ (Van Dormael 1978, 200-1)

Hence the major and crucial difference between the Final Act and the radical proposals of Keynes and Sempill was the presence of a national currency as the reserve in support of exchange rate stability, and thus as the method of controlling excessive external imbalances. What Robert Triffin was to identify as the Achilles heel of the postwar international financial architecture was adopted without discussion of its implications. Its importance is in how it changes the way limits and sanctions are imposed on payments imbalances. In the Keynes and Sempill proposals, it is the tax or interest charge on the credit and debit balances, and multilateral negotiation over additional remedies, such as exchange rate adjustment, when limits are breached. In the final Bretton Woods system, the limits on imbalances are given by the ability to preserve par value for the national currency and, given the concentration of gold in the United States, on the country's ability to generate dollar reserves. Beyond this limit, there was an automatic extension in the form of the ability to draw the gold tranche, but after that it was given by the conditionality attached by Fund staff to additional program lending. This approach was thus predicated on the expansion of dollar reserves in the rest of the system, which required the United States to become a serial debtor and, as Triffin noted, would reduce its ability to preserve the dollar value of gold. This system preserved market-determined exchange rates, and the speculative activity concerning possible parity adjustment, through what were described as

\footnotetext{
${ }^{16}$ This crucial change in the proposals "was made on 6 July, at the 2.30 p.m. meeting of Committee 2" in an "alternative, submitted by the American delegate, [which] provided that 'The par value of the currency of each member shall be expressed in terms of gold, as a common denominator, or in terms of a gold-convertible currency unit of the weight and fineness in effect on July 1, 1944.' . . . There was no further discussion, and the alternative was approved. ... The second move was made a week later. .. . Harry White was chairman. ... One of the points to be discussed was the date on which countries joining the Fund should make their initial contribution of gold and gold-convertible exchange. This was a minor point, and, since the 'delegations did not have time to consider the matter, the Committee agreed to refer this question directly to your Commission'. The Indian delegate asked for a definition of gold-convertible currency, which had been discussed, and of which Keynes had said it did not exist. The question as put related to the gold-convertible contributions only, and not to the par value of currencies. Robertson, against Keynes's instructions, but as the responsible British delegate, suggested that the words 'gold and gold-convertible currency' be replaced by 'net official holdings of gold and U.S. dollars', and remarked that this would involve several changes elsewhere. This was White's opportunity. Using his authority as chairman, he referred the matter to a special committee, which took it out of any further discussion. ... The change from 'gold' to 'gold and US dollars' was lost in the ninety-six page document the chairmen of the delegations would sign a few days later. Whether or not any of them noticed it, or understood its implications, it seems that none of them expressed any reservations about it. Keynes would not find out until later, when he studied the Final Act" (Van Dormael 1978, 201-3).
} 
the "gnomes of Zurich" but were simply short-term capital flows taking what was a one-way bet on parity adjustments.

Again, Keynes proved to be correct about the destabilizing role of asymmetric adjustment (he was sanguine about the dollar short, believing that it would soon disappear, making the "scarce currency" clause irrelevant), for this also proved to be the downfall of the dollar-gold system. When the United States was faced with a loss of its gold reserves below the level required to redeem outstanding foreign dollar claims at the Bretton Woods parity, it executed a series of administrative measures, such as interest equalization and operation twist, instead of internal adjustment. When these measures failed, and in the presence of the refusal of Germany and others to revalue, the United States simply exited the system — which is, of course, precisely what happened under the gold standard: the deficit country would just suspend convertibility when the adjustment burden became too great.

\section{Bretton Woods Loses Control of External Balances}

After the breakdown of the Smithsonian Agreement and the introduction of flexible exchange rates, the rise of private capital flows in international markets brought Keynes's third element of instability to the fore, and private capital flows came to dwarf the resources available to the IMF. And it soon re-created the problem of international indebtedness. But the real problem was that in a flexible rate system there was no longer any mechanism to limit external imbalances. Capital tended to flow into the debtor countries without limit, in the presence of perverse incentives for interest arbitrage. Countries that attempted to respond to external imbalance by tightening monetary policy to reduce the level of activity were met by flows of interest rate arbitrage funds, which caused the currency to appreciate even in the presence of deteriorating external balances. The only limit on this process then became the expectations of speculators, with capital reversal generating a financial crisis, which then imposed external adjustment. The system that was chosen in order to avoid the automatic creation of credit via the banking principle produced a system with no limits on either imbalances or on global credit creation-or rather, the limit on the size of imbalances was set by the point at which investors realized that they were financing their own debt service (in what was clearly a Ponzi scheme) — and a capital flow reversal resulted in a financial crisis. The IMF was reduced to the role of credit collector, called in to impose policies that would ensure a sufficiently large negative net flow of resources to repay private lenders, at the expense of domestic growth an employment. 
It is this boom-bust cycle of capital flows and exchange rate volatility that emerging markets find debilitating. But it should be evident that a substitution of the dollar with an international reserve currency is not the appropriate solution for emerging market economies, as this would merely restore the gold standard and revive the concerns about the governance of global liquidity creation. Indeed, it might make it worse, for a common currency would eliminate even the uncertainty on speculative flows that was created by the spread of the gold points. The experience of the European Union provides a picture of the difficulties that would be faced by the attempt to create a global currency. ${ }^{17}$

\section{The Clearinghouse Proposals Meet the Problems of Emerging Market Economies}

Given the historical experience of the negotiations and the performance of the structure launched at Bretton Woods, it would seem obvious that the aspects that emerging market economies find objectionable cannot be fixed by means of the policy proposals they have put forward. It is the structure that has to be changed, and the structure of the Keynes-Sempill proposals would seem to meet the criticisms more directly.

Under these more radical proposals, there can be no currency wars, no wall of money, and no interest rate arbitrage. Foreign investment by any country is limited by its global current account position. Indeed, there would be no need for discussion over the efficacy of capital controls, or whether they should be on inflows or outflows or monitored by the creditor country central bank or the debtor country central bank. As Keynes had envisaged in his original proposal, "international capital movements would be restricted so that they would only be allowed in the event of the country from which capital was moving having a favourable balance with the country to which they were being remitted" (1980, 16-17). Capital flows would extinguish foreign credits in the same way as imports, and thus would only be "allowed when they were feasible without upsetting the existing equilibrium" on external account (17).

Thus, replacing the dollar with a nonnational currency or the SDR will not eliminate the problems facing emerging markets; nor will increased multilateral cooperation, even if that

\footnotetext{
${ }^{17}$ Keynes's proposal is often presented as the creation of a "global currency," but his proposed "bancor" was a notional unit of account and could not be spent by private individuals or used as the basis for private bank credit creation; indeed, it was not essential to the principle of net clearing. After it was clear that it was unacceptable to the United States, Keynes eventually supported the "monetisation" of the US proposal for "unitas" to facilitate government acquisition of currencies outside the Fund. It was his attempt to move the stabilization fund closer to his clearing union. (See Keynes 1980, 342; Skidelsky 2001, 316.)
} 
could be achieved. The creation of financial institutions governed by regional or other restricted groupings does create the most important possibility, but not in the form in which they are currently being discussed. The current proposals are primarily designed to escape the inadequate governance of the IMF and the World Bank and the dominance of the United States in both the theory and practices of these institutions. In addition, as noted above, they usually take the IMF as their template and at some level of financial commitment impose IMF program conditionality.

There is no reason why these institutions cannot be created on the template of the Keynes-Sempill clearing unions, building on the swap agreements that many countries have already agreed to on a bilateral basis. Thus, the creation of a common currency for the members of the Bank of the South may not be the most sensible proposal, but the creation of a regional clearing union with a notional unit of account would provide a remedy to the problems faced by these countries. Indeed, Keynes had already considered this as a possibility:

One view of the post-war world which I find sympathetic and attractive and fruitful of good consequences is that we should encourage small political and cultural units, combined into larger, and more or less closely knit, economic units. ... Therefore I would encourage customs unions and customs preferences covering groups of political and geographical units, and also currency unions, railway unions and the like. Thus it would be preferable, if it were possible, that the members should, in some cases at least, be groups of countries rather than separate units. $(1980,55)$

Thus, the currently proposed financial institutions could be cast in the form of clearing unions.

Indeed, there is already a historical precedent for the operation of a regional clearing union in the European Payments Union, which played an integral part in the restoration of intraEuropean trade and payments to complement the Marshall Plan. ${ }^{18}$ This might provide a better template for the emerging markets initiatives than the IMF.

\section{But They Do Not Necessarily Meet the Needs of Developing Countries in General}

Aside from Latin American countries, few developing countries were present at Bretton Woods. India was still represented by Great Britain and the Chinese presence was apparently a question

\footnotetext{
${ }^{18}$ See Kaplan and Schleiminger (1989) for a political and analytical description of the operation of what was in integral part of the restoration of multilateral trade and payments in Europe. It is somewhat ironic, given the inability of the Bretton Woods Fund scheme to operate in the immediate aftermath of the war, that a scheme similar to Keynes's should in fact be adopted, although subject to the constraints of the postwar economic conditions.
} 
of American political expediency. Indeed, in the discussions of the clearing union there was virtually no consideration of developing countries. This was primarily because the focus was on postwar reconstruction finance. It was only in the discussion of the collateral issues of commercial policy and commodity support schemes that development questions emerged — and they were quickly separated from the financial discussions because they were considered a threat to rapid approval of the international financial reforms. ${ }^{19}$

Only Schacht's original proposal for a clearing union directly concerned developing countries; but, as noted above, this was mainly about financing German inputs of primary materials and providing a market for German exports, rather than laying out a positive development agenda. The other proposal that took developing country concerns into account, if only generally, was John H. Williams's assessment of the postwar proposals; namely, that their "fundamental requirement is the maintenance of an even [external] balance, with only temporary fluctuations from it" (Williams 1949, 158) and that this presumes the same principle as the gold standard, which was "based on the principle of interaction between homogenous countries of approximately equal size" (173).

Recognizing that different countries might require different currency schemes, Williams included only the major "key" currencies in his proposal. He raised the question of whether "the world needs a single, uniform system or a combination of different systems by consideration of the diversity of countries, and in particular the differences in their proportions of home and foreign trade" (189). This line of reasoning leads directly to the needs of countries with different export compositions and the problems faced by countries with primarily commodity dependence that were to be raised by Raúl Prebisch, Hans Singer, Gunnar Myrdal, and others. For these countries may require sustained periods of external deficit (foreign finance of industrialization) or external surplus (export-led development), which is directly contrary to the basic principle of equilibrium external balance as the key to international financial stability. The same is true of multiple exchange rates, which many economists have suggested may play a crucial role in building a more balanced, productive structure in developing countries (e.g., Kaldor 1965,

\footnotetext{
${ }^{19}$ The British postwar planning was comprehensive: in addition to Keynes's currency plan, there was a proposal for a "commod" to stabilize primary materials prices, a commercial union (largely the work of James Meade), and an international investment board and development corporation. The latter was apparently the result of a 1941 proposal by Luther Gulick and Alvin Hansen, advising the State Department on postwar reforms, and is mentioned in Keynes's drafts of the clearing union. However, given the antipathy between the US Treasury and the State Department, once the former had started work, it consistently excluded the latter from the development of reforms.
} 
Diamand 1978) but which are expressly excluded under Bretton Woods because of the experience of German rearmament.

Keynes's clearing union approach is just as deficient in this respect, as the stabilization fund and some special measures would have to be included to allow for developing countries to have relatively larger debit (or credit) balances and to eliminate the sanctions on such balances, since they would be the result of a successful development policy. Otherwise, countries that have used either import substitution or export-led growth strategies that are too successful could find themselves facing additional charges and pressure to rein in or adjust their successful policies in order to keep their external accounts within acceptable ranges. These special measures might include exemption on the size of balances and remission of the interest charges for developed country creditors and developing country debtors. Alternatively, the Bank could have been fashioned as a more development-centered institution and made an integral part of the IMF. Or, more simply, an alternative clearing union institution for developing countries could have been proposed. Clearly, a balanced external account may be the most appropriate objective for the international financial stability of developed countries, but it certainly need not be so for developing countries. Indeed, multilateral institutions and the United Nations have consistently argued for the transfer of resources from developed to developing countries in magnitudes of 0.7 percent of developed country GDP, which would presumably generate interest charges on the resulting deficits and surpluses for the donor and recipient countries (see, by way of comparison, Kregel 2015).

\section{Stable Exchange Rates and Monetary Sovereignty}

From the point of view of the current difficulties facing emerging market economies, the basic advantage of the clearing union schemes is that there is no need for an international reserve currency, no market exchange rates or exchange rate volatility, and no parity to be defended. Notional exchange rates can be adjusted to support development policy, and there is no need to restrict domestic activity to meet foreign claims. Indeed, there is no need for an international lender or bank, since debt balances can be managed within the clearing union. The external adjustment occurs by creating an incentive for export surplus countries to find outlets to spend their credits, which may be in support of developing countries. The system thus supports global demand. Since all payments and debts are expressed in national currency, independence in national policy actions and policy space are preserved. In modern terminology, countries retain 
monetary sovereignty within the constraint of external balance, which should correspond to full utilization of domestic resources.

Such a system would reflect Keynes's broader vision of the appropriate role for international financial flows:

I sympathize, therefore, with those who would minimize, rather than with those who would maximise, economic entanglement between nations. Ideas, knowledge, science, hospitality, travel - these are the things which should of their nature be international. But let goods be homespun whenever it is reasonably and conveniently possible; and, above all, let finance be primarily national. (Keynes 1982, 236) 


\section{References}

Beyen, J.W. 1951. Money in a Maelstrom. London: Macmillan.

Blanchard, O., J.D. Ostry, and A.R. Ghosh. 2013. "International Policy Coordination: The Loch Ness Monster." iMFdirect, December 15.

Bloomfield, A. 1959. Monetary Policy under the International Gold Standard: 1880-1914. New York: Federal Reserve Bank of New York.

China Briefing. 2010. "Chinese Yuan Seeks Further Internationalization and Less Reliance on U.S. Dollar.” December 9.

Clarke, S.V.O. 1967. Central Bank Cooperation 1924-31. New York: Federal Reserve Bank of New York.

Diamand, M. 1978. "Towards a Change in the Paradigm of Development Through the Experience of Developing Countries." Journal of Development Economics 5 (78): 1953.

Economic Reform Club (attributed to Lord Sempill). 1941. "A Twentieth Century Economic System." London: Economic Reform Club.

Goyal, K. 2014. "Rajan Warns of Policy Breakdown as Emerging Markets Fall.” Bloomberg Business, January 31.

IMF (International Monetary Fund). 2014. "2014 Spillover Report: IMF Multilateral Policy Issues Report.” IMF Policy Paper. Washington, D.C.: IMF. July 29.

Kaldor, N. 1965. "Dual Exchange Rates and Economic Development." Reprinted in Essays on Economic Policy, Vol. 2. New York: W. W. Norton.

Kaplan, J.J., and G. Schleiminger. 1989. The European Payments Union: Financial Diplomacy in the 1950s. New York: Clarendon Press.

Keynes, J.M. 1943. International Clearing Union. 28 Parl. Deb., H.L. (5th ser.) (1943) 527-37. 1971a. The Collected Writings of John Maynard Keynes. Edited by D. E. Moggridge. Vol. 4, A Tract on Monetary Reform. London: Macmillan.

1971b. The Collected Writings of John Maynard Keynes. Edited by D. E. Moggridge. Vol. 6, A Treatise on Money, Vol. Two: The Applied Theory of Money. London: Macmillan.

1980. The Collected Writings of John Maynard Keynes. Edited by D. E. Moggridge. Vol. 25. Activities 1940-1944. Shaping the Post-war World: The Clearing Union. London: Macmillan. 
1982. The Collected Writings of John Maynard Keynes. Edited by D. E. Moggridge. Vol. 21, Activities 1931-1939: World Crises and Policies in Britain and America. London: Macmillan.

Kregel, J. 2015. “Cognitive Dissonance: Post-war Economic Development Strategies and Bretton Woods International Financial Stability." In M. Damill, M. Rapetti, and G. Rozenwurcell, eds. Macroeconomics and Development. New York: Columbia University Press.

Lüke, R. 1985. “The Schacht and Keynes Plans.” BNL Quarterly Review 38 (152): 65-76.

Oliver, L. 2009. "SDR vs the Dollar: China and Russia Want SDRs.” Euromoney, April 1. www.euromoney.com/Article/2172502/SDR-vs-the-Dollar-China-and-Russia-wantSDRs.html.

Reuters Factbox. 2009. "The Appeal of the IMF's Special Drawing Rights.” March 24.

Schacht, H. 1949. Account Settled. Translated by Edward Fitzgerald. London: Weidenfield \& Nicolson.

. 1955. My First Seventy-Six Years. Translated by Diana Pyke. London: Wingate.

Sempill, The Lord. 1941. The Atlantic Charter: Economic Security. Parl. Deb., H.L. (5th ser.) (1941) 45-64.

Skidelsky, R. 2001. John Maynard Keynes, Vol. 3: Fighting for Freedom, 1937-1946. New York: Viking.

The Social Crediter. 1943. "From Week to Week." January 2.

Spicer, J. 2014. “Cool Reception for India Central Banker Urging Global Cooperation.” Reuters, April 10.

Triffin, R. 1960. Gold and the Dollar Crisis: The Future of Convertibility. New Haven: Yale University Press.

Van Dormael, A. 1978. The Bretton Woods Conference: Birth of a Monetary System. New York: Holmes and Meier.

Volcker, P., and T. Gyohten. 1992. Changing Fortunes: The World's Money and the Threat to American Leadership. New York: Times Books.

Wheatley, J. 2014. "Brazil Achieves a Hollow Victory in 'Currency Wars.'” Financial Times, November 17.

Wheatley, J., and P. Garnham. 2010. "Brazil in 'Currency War' Alert.” Financial Times, September 27. 
Williams, J.H. 1949. Post-war Monetary Plans and Other Essays. Oxford: Basil Blackwell. Zhou, X. 2009. "Reform the International Monetary System." Basel: Bank for International Settlements. March 23. 